\title{
Days in Laboratory
}

by

\author{
Koki TERASAWA*
}

この度, コンクリート工事用樹脂部門委員会からご 推薦いただき，会員便りを執筆する機会をいただきま した。本稿では自己紹介も兼ねて研究室生活の思い出 と最近考えていることについて書かせていただきたい と思います。

大学にはコンクリートの研究室というものがあるらし い, ということを初めて知ったのは高校 3 年生の時でし た. 受験を意識し始めた頃に, 志望学部を決めるべく色々 な大学のパンフレットだったか冊子のようなものに目を 通していた時, 様々な研究室を紹介しているページが目 に留まりました，そのページは研究内容を紹介する文章 とともに1枚の写真を載せる構成で, 多くの研究室はメ ンバーの集合写真だったり, 研究室でパソコンを操作す る様子などが掲載されていましたが，そのコンクリート の研究室が載せていた写真には, つなぎ姿で円柱のコン クリート供試体を両手に持っている皆さんの姿がありま した．実験室での一枚と思いますが，その笑顔がとても 印象的で強く記憶に残っています。その当時はまさか自 分が同じくコンクリートに関連する研究をしていくこと になるとは想像もしていませんでした。

その後, 京都大学工学部地球工学科に入学し, 学部 4 年次の研究室配属で河野広隆先生の構造物マネジメン 卜研究室の一員となりました。卒業研究は, 先生にご 提示いただいたテーマの中から「磁石を使ってコンク リートの中の鉄筋破断を検出する方法」を選びました。 これは，一般的にコンクリートがほぼ非磁性体である のに対して，コンクリート内部に配置される鉄筋は強 磁性体であることを利用した非破壊検査手法で，鉄筋 の破断箇所に生じる磁極の影響をコンクリートの表面 から捉えるというものです。コンクリート構造物の維 持管理について考える上で, コンクリートに対してア プローチをするテーマを持つ研究室の仲間が多い中で 「コンクリートそのものの様々な影響を考えるのではな く, 内部の鉄筋のみに着目したアプローチは面白そう だなあ」と感じ，手を挙げてみましたが，この選択が 個人的には幸運だったと今になって思います。コンク リート構造物を対象とした非破壊検査にはその目的に 応じた様々な手法が提案されていますが, 多くの手法 では骨材・セメントおよび水から成る複合材料である コンクリートの不均一性に起因する計測結果のばらつ きはある程度生じるものと考えられます。一方，この 研究ではコンクリート自体の影響をほぼ受けないため,
実験を行うと予想通りにしろ予想外にしろ素直な結果 が得られるので，検討のしがいがあり実験をすること がとても面白く感じられました。そして「こんなこと もやってみたい」「あの影響も見てみたい」と思わず夢 中になって研究に没頭することができました，良い結 果が出たと思った実験でやり方の間違いに気づき，年 末に一人実験室に籠ってやり直しをしたりと失敗もた くさんありましたが, 気づけば修士・博士課程まで研 究を続けさせていただきました.

学位取得後, 大阪大学大学院工学研究科の社会基盤 工学講座に助教として着任しました。現在 6 年目とな りますが，鎌田敏郎先生とともにコンクリート構造物 の非破壊検査に関する研究を進めています。研究室で は複数人の学生で検討対象に応じた非破壊検査手法の チームを結成しており，例えば床版のひび割れを対象 とした「衝撃弾性波法チーム」, PCグラウトの充填不 良やあと施工アンカーボルトの接着剤充填不足を対象 とした「電磁パルス法チーム」などがあります。その 中で，私が学生時代に行っていた磁石を用いた検査手 法である「漏洩磁束法チーム」もあり, 現在は鋼材の 腐食に伴う磁気特性の変化に着目し, コンクリート中 の鉄筋の腐食を対象とした研究や，プレストレストコ ンクリートにおける PC 鋼材の緊張力変化を評価する手 法の検討などを行っています。

学生と接していて最近感じることとしては, 学部卒 業後に修士課程までは進んだとしてもその先の博士課 程までは進みたがらない, という印象があります。こ れは今に始まった話ではないかもしれませんが，しっ かり研究をしているなあと思える学生がいたとしても, 最初から博士課程への進学という選択肢を考えていな いように見えるのは, 研究室の教員側で学生に近い立 場として改善すべき点があるのではと感じています. 就職という選択肢が決して悪いわけではありませんが, 私のように「この研究をもっと進めたい!」と強く感 じられる研究テーマを与えられることが, 学生にとっ て進学という選択肢を考える第一歩になるのではない かと思います.

自分自身が学生時代に味あわせてもらった「自由に 研究できることの楽しさ」を学生にも感じてもらえれ ば，いつか見た写真のように笑顔溢れるコンクリート 研究室にもっと近づければ, などと考えながら, 学生 と共に勉強し奮闘する日々を過ごしています.

原稿受理＼cjkstart令和 2 年 3 月 10 日 Received Mar. 10, 2020 C2020 The Society of Materials Science, Japan

* 正会 員 大阪大学地球総合工学専攻 † 567-0871 吹田市山田丘, Division of Global Architecture, Osaka Univ., Yamadaoka, Suita, 567-0871 